\title{
THE MUSICAL PATRONAGE OF THE HOUSE OF HABSBURG IN JESUIT SILESIA
}

\author{
TOMASZ JEŻ \\ Uniwersytet Warszawski
}

Izvleček: Eden od pomembnih dejavnikov v rekatolizaciji Šlezije v 17. stoletju je bila glasbena umetnost po vzorih sodobnega italijanskega sloga, ki so jo širili predvsem krogi, povezani z jezuiti. Finančno jih je podpirala tedanja politična elita obravnavanega prostora, pretežno povezana s Habsburžani.

Ključne besede: podporniki glasbe, jezuiti, Habsburžani, Šlezija.
Abstract: An important factor in the Catholic reconquest of Silesia in the seventeenth century was the cultivation of music modelled on the Italian style, which was promoted by circles connected with the Society of Jesus and financed by the new political elites of this region, ones predominantly linked to the House of Habsburg. Keywords: musical patronage, Jesuits, Habsburgs, Silesia.

The Roman polymath Athanasius Kircher dedicated the first edition of his monumental treatise Musurgia universalis (1650) ${ }^{1}$ to Archduke Leopold Wilhelm of Austria (1614-1662), who was also Governor of the Spanish Netherlands and Prince-Bishop of Halberstadt, Passau, Breslau, Olomouc and Strasbourg. The Prince administered these dioceses by virtue of a political appointment despite not possessing the appropriate canonical qualifications. On the dedication page of Kircher's treatise (figure 1) he is shown wearing a bishop's robes, but the portrait is captioned with his secular titles, "Archidux Austriae Belgii et Burgundiae Gubernator", and accompanied with military emblems.

Confusing the appurtenances of spiritual and secular power can be considered a signum temporis during the period of the Thirty Years' War, when politics was tied up with religion in what can be seen as a Gordian knot. That the Muses did not fall silent during that time was a consequence of the practical functions assigned to art by both secular and ecclesiastical rulers in Europe, including the House of Habsburg, which controlled half of the continent. The Habsburgs' achievements as patrons of art have been widely acknowledged and are associated with a specific type of piety that left a permanent mark on the artistic culture of the social milieus subjected to Habsburg influence. The Jesuits played a major role in the formation of the Pietas Austriaca. Although their influence was supposed to be limited to the spiritual sphere, in their role as confessors to emperors,

1 Kircher, Musurgia. 


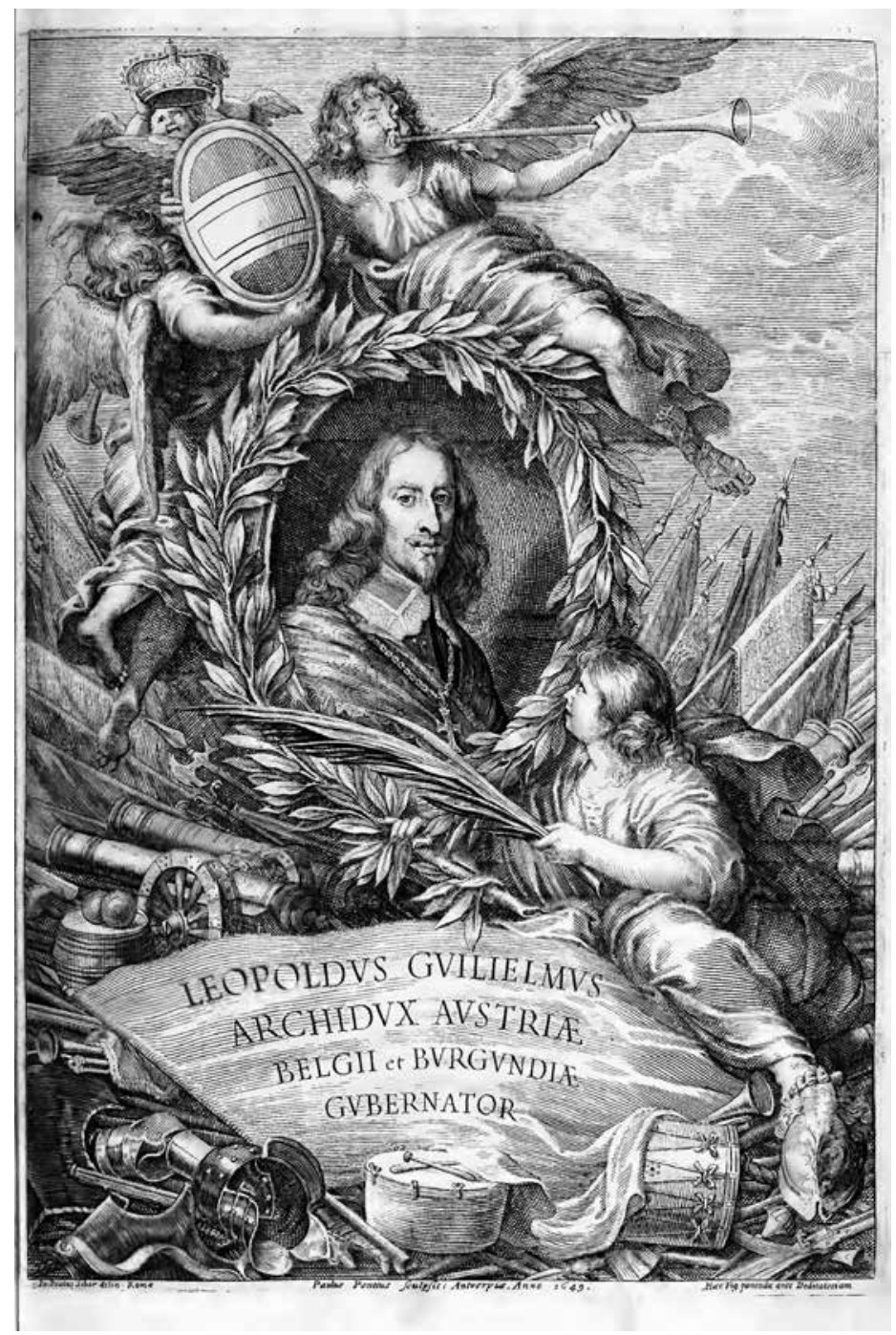

\section{Figure 1}

The dedication page of Musurgia universalis by Athanasius Kircher (1650; available online on http:// imslp.org)

kings and princes the maintenance of this kind of strict division between spirituality and politics proved impossible. By engaging in politics, the Society of Jesus entered into a kind of symbiosis with the structures of power in Catholic countries, and this relationship brought advantages important to the functioning of both parties. ${ }^{2}$

One of the beneficiaries of this symbiosis was music cultivated at the meeting point of both worlds, which similarly owed much to the Jesuits. This culture flourished especially well in territories considered by the Jesuits to be areas of missionary activity where musical practice was to be permitted on a much larger scale than elsewhere. Of special interest in this context is the Catholic musical tradition of Silesia, revived in the period

2 Bireley, Religion and Politics, 9-31. 
of the Thirty Years' War, which was particularly difficult for that region. ${ }^{3}$ The historical backdrop for these phenomena is provided by the musical tradition at the court of the Austrian dukes in Graz, who later also gained the imperial crown. This fact was of much consequence for the artistic culture of countries where supreme power was held by the Holy Roman Emperors, and which at the lower levels of authority were frequently also ruled by members of the Habsburg family. ${ }^{4}$

This cultural symbiosis between Habsburgs and Jesuits yielded its first fruits in Austria itself, where the Jesuits had settled with the active support of Karl II, Archduke of Austria (1540-1590) and, later, his son Ferdinand (1578-1637), both of whom were renowned patrons of art who never spared any expense for music, especially when this formed part of the religious affairs. ${ }^{5}$ Ferdinand's cultural ambitions become evident if we consider the significant number of Italian musicians in his employ and the Italianate style of the music they performed. A large portion of the ensemble's repertoire consisted of concerti sacri for small voice-combinations in the manner of the seconda pratica, as published in the anthology Parnassus Musicus Ferdinandeus, which was compiled by Giovanni Battista Bonometti and dedicated to the Archduke. ${ }^{6}$ The concertos in this anthology were composed almost exclusively by Italian musicians serving at Ferdinand's court. One exception is Georg Poss (c. 1570-post-1633), a native of Franconia who, however, studied for three years in Venice. 'The last composer's oeuvre sheds light on the ideological context for the activity of the Archduke's Hofkapelle, which served Ferdinand as "an effective instrument for the propaganda fides catholica". Symptomatically for this context, one of Poss's works contained in the above-mentioned anthology (Hic est beatus Carolus) was in veneration of St Carlo Borromeo, Archbishop of Milan and a Tridentine cardinal, who became a patron of the post-Tridentine Catholic revival.

Poss's surviving output of compositions includes two single-authored publications (from several years earlier), one of which contains several missae parodiae ${ }^{9}$ - a genre that enjoyed especial popularity among some post-Tridentine Catholic circles, who praised the intelligibility of the texts. The other print is an atypical collection in which strictly liturgical motets are juxtaposed with rather secular occasional pieces dedicated to members of the Archduke's family. ${ }^{10}$ This collection likewise betrays the influence of Jesuit teaching in motets dedicated to three leading Jesuits: Ignatius of Loyola, Francis

3 Jeż, Kultura muzyczna jezuitów na Śląsku, 26-82.

4 Saunders, Cross, Sword, and Lyre.

5 Lamormaini, Ferdinandi II. Römischen Khaysers Tugenden, 86.

6 Federhofer, "Graz Court Musicians", 167-244.

7 Federhofer, Musikpflege, 195-198.

8 Federhofer, "Graz Court Musicians", 169.

9 Poss, Liber primus missarum.

${ }^{10}$ Poss, Orpheus mixtus, 30-31. Mollia purpureas pingunt-O Coniunx per chare. Pro nuptijs Serenissimi Ferdinandi Archiducis Austriae; 32. Arctoi perimit frigora syderis. In faelicem ex Polonia reditum Serenissimae Matris \& Sobolum Archiducum Austriae; 42. Quantis Austriadum. Gratulatio in recens natum Ioannem Carolum Archiducem Austriae; 43. O orbis inclytum decus. In faelicem ex Italia reditum Serenissimi Maximiliani Ernesti Archiducis Austriae; 44. Frà quante il sol alluma. In lode del Serenissimo Ferdinando e della sua Serenissima Marianna. 
Xavier and Edmund Campion - none of whom had at the time of publication been either beatified or canonised. ${ }^{11}$ A similar precedent was established in 1619, when the famous portrait of Ignatius of Loyola by Peter Paul Rubens with a discreetly painted halo was presented for liturgical use. ${ }^{12}$

Other motets from Bonometti's anthology display similar features of post-Tridentine spirituality. These include some composed by two Italian musicians serving in Archduke Ferdinand's orchestra. When Ferdinand became Emperor (1619), these two men successively held the post of Kapellmeister in his Viennese Hofkapelle. The style of musical narration displayed in motets by Giovanni Valentini (c. 1582-1649) is highly emotional. For instance, $O$ dulcis amor Jesu makes use of the meditations by St Bernard of Clairvaux, popular in Jesuit circles and practised by Ferdinand II himself, while Anima Christi sets the text of the famous Eucharist prayer by Ignatius of Loyola. ${ }^{13}$ The same Jesuit-influenced focus of religious references is present in Valentini's Passion motets from his Sacri concerti, a collection published already during the composer's Viennese period. ${ }^{14}$ Compositions such as Salve tremendum show a close affinity to the meditations on the wounds of Christ popularised by Jesuit writings from that period, which played a major role in the development of the Viennese genre known as the sepolcro, forerunners of which were the semi-dramatic motets of Giovanni Valentini. ${ }^{15}$

A diametrically opposed style is represented by the occasional pieces for the Viennese Hofkapelle composed for the coronations of emperors or in celebration of their military victories. Valentini proved highly proficient in this genre; he combined Biblical texts for liturgical use with political propaganda. ${ }^{16}$ This peculiar blend of piety and Machtpolitik found its musical manifestation in large-scale monumental settings enriched by additional trumpet parts and featuring vocal melodies in similar style. Liturgical music for ordinary (ferial) days of the week was similarly performed in front of the Emperor and his guests, and could therefore also be imbued with political meanings. Eulogistic operatic spectacles ${ }^{17}$ and the related genre of Jesuit school drama ${ }^{18}$ likewise served the purposes of a propagandistic demonstration of the pax austriaca. This tradition was cultivated by Ferdinand II and continued by his son, Ferdinand III (1608-1657), for whom "cultural hegemony was crucial to maintaining political cohesion". ${ }^{19}$ Music played a key role in

${ }^{11}$ They are the following works: 24. Dum vultum in superos Ignatius emigrat orbes. De B. P. Ignatio; 25. Funera mille premunt Francisce pericula. De B. P. Xaverio; 26. Spectamur coelo mundo spectamur. De B. P. Edmundo. The three Jesuits were beatified (respectively) in 1609 , 1619 and 1886, and canonised as late as 1622, 1622 and 1970.

${ }^{12}$ Peter Paul Rubens, The Miracles of Saint Ignatius of Loyola, oil on canvas, $535 \times 395 \mathrm{~cm}$. Vienna, Kunsthistorisches Museum.

${ }^{13}$ The second piece was published in Valentini, Salmi, hinni. Cf. Saunders, Cross, Sword, and Lyre, 6, 132.

${ }^{14}$ Valentini, Sacri concerti (print not listed in RISM A/I). Saunders, Cross, Sword, and Lyre, 205-219.

15 Saunders, Cross, Sword, and Lyre, 55.

${ }^{16}$ Saunders, "The Hapsburg Court of Ferdinand II", 378-379.

${ }^{17}$ Seifert, Die Oper.

${ }^{18}$ Federhofer, Musikpflege, 41-42.

${ }^{19}$ Saunders, "Der Kaiser als Künstler", 187. 
this effort as a perfect instrument of persuasion in the service of Counter-Reformation propaganda.

A similar ideological background to musical performances can be postulated also for the court of Ferdinand II's youngest brother, Karl Habsburg (1590-1628), who completed a Jesuit education and served as a canon in Salzburg (1602), Brixen and Passau (1605). In 1608 he became the Bishop of Breslau and five years later (1613) also that of Brixen, and in 1619 he was made Grand Master of the Teutonic Order. Following in the footsteps of his parents and siblings, Karl Habsburg created at his residence in Neisse a fully-fledged musical ensemble, for which, in 1614, he secured several musicians in the service of Archduke Ferdinand, including Giovanni Valentini. ${ }^{20}$ Before this composer was recalled by Ferdinand to his court in Vienna, he dedicated to the Bishop of Breslau one of his prints published in 1618. ${ }^{21}$ Although the composer signed his dedication when back in Graz, the compositions contained in this volume may arguably have been performed also in Silesia - for example, during Ferdinand's visit to Breslau and Neisse in September 1617, on which occasions the Archduke's orchestra, travelling with the archduke, performed a Te Deum. ${ }^{22}$

Testimony to the widespread popularity of Valentini's music in Silesia can be found in the manuscript Bohn 204 from the collection of Michael Büttner - cantor of the Church of St Mary Magdalene in Breslau in 1634-1662, ${ }^{23}$ which includes copies of five large-scale liturgical compositions by Valentini: two Masses (Missa primi toni a 10 and Missa concertata a 8 o 16), a Magnificat parody (Magnificat tertii toni super Beata viscera a 17), two mixed vocal-instrumental concertos, Benedicam Dominum in omni tempore a 14 for three choirs and Gelobet sei der Herr der Herrlichkeit a 17 for four choirs, and finally an instrumental Sonata a 5. In the Bohn 20 tablature from the collection of the same church one can find the concerto Deus misereatur nostri a $C$ e $B$ for a small number of voices, and in Ms Bohn 37 another solo piece by Valentini: Confitebor tibi Domine a T vel C solo.

In 1618-1622 the post of Kapellmeister at Karl Habsburg's court was held by Georg Poss, who had also previously served in the Graz orchestra. ${ }^{24}$ Traces of his presence in Silesia have been preserved in the tablature Bohn 20 from Breslau, which contains a copy of his Missa super Jubilate Deo a ${ }^{25}$ included in the already mentioned print of Masses. ${ }^{26}$ Evidence of the Silesian bishop's preference for the Italian style can also be found in his correspondence, which reflects his efforts to secure Italian musicians for his ensemble. ${ }^{27}$ His negotiations led to the employment in 1622 of Stefano Bernardi (1577-1637), previously the maestro di capella at Verona Cathedral, and of Antonio Cifra (1584-1629), the former Kapellmeister of the Collegio Germanico in Rome and Santa Casa in Loreto. The

${ }^{20}$ Przybyszewska-Jarmińska, "Starania biskupa wrocławskiego", 129.

${ }^{21}$ Valentini, Salmi, hinni.

${ }^{22}$ Kastner, Archiv für die Geschichte, 170-171.

${ }^{23}$ Bohn, Die musikalischen Handschriften, 173-174; Wiermann, Die Entwicklung, 465-475. Manuscripts from the Bohn collection are now held by the Deutsche Staatsbibliothek, Musikabteilung, Berlin (D-Bds).

${ }^{24}$ Federhofer, "Graz Court Musicians", 181.

${ }^{25}$ D-Bds, Slg. Bohn 20, 276.

${ }^{26}$ Poss, Liber primus missarum.

${ }^{27}$ Przybyszewska-Jarmińska, “Starania biskupa wrocławskiego”, 129-132. 
six pieces by Cifra copied into the Silesian organ tablature Bohn 46, also published in three consecutive books of his motets ${ }^{28}$ come from the period of the composer's close collaboration with the Roman Jesuits (1605-1609). Two of them are settings of texts typical of Jesuit spirituality: Jesu dulcis memoria and O Jesu mi dulcissime. It was Cifra who made an inventory of Karl Habsburg's property after the bishop's death.

One of Karl Habsburg's first decisions as bishop was to invite the Jesuits to Silesia, where they established their missionary stations in Neisse and Ratibor. Before he founded Jesuit colleges in Silesia, Karl bequeathed to the Jesuits from nearby Glatz a foundation (1614) that allowed the order to open a boarding school in that city ${ }^{29}$ and finance music education for twelve students from Silesia. During their education the students were obliged to provide liturgical music for the parish church administered by the Jesuits. At the Jesuit college in Glatz (established already in 1597) music performances had also taken place earlier - for instance, in 1605, when the college played host to the Archdukes Ferdinand and Maximilian, who were escorting their sister to her wedding to King Sigismund III Vasa. On that occasion, the Jesuits from Glatz staged a spectacle for their honoured guests, the performers for which were students from the Jesuit gymnasium. ${ }^{30}$ From what we know of the musical tastes of the Austrian Archdukes, such a spectacle would not have been mounted without music. Moreover, on their journeys between Graz and Cracow the Habsburgs were usually accompanied by Italian musicians (Bartolomeo Mutis, Antonio Patart, Hippolito Bonanni and Giovanni Valentini) ${ }^{31}$ seeking employment at the court of the Polish king or returning from service in Poland.

The college students from Glatz also presented musical-theatrical spectacles in honour of their benefactor, bishop Karl Habsburg. During one of his visits (1609) they staged for him a play about St Paulinus, ${ }^{32}$ and two years later they performed vocali ad coenae nobiles variis concertationibus and presented a short drama with elements of dance. ${ }^{33}$ It was Karl's ambition to open a Catholic studium universale in Silesia. ${ }^{34}$ When the first phase of the Thirty Years' War subsided, the Bishop of Breslau founded in Neisse a Jesuit college (1622) and a gymnasium under Jesuit administration with an extended syllabus in philosophy and theology (later known as the Collegium Carolinum), which was conceived as the starting point for a future university. In the first year of its operation two plays were staged in honour of the founder: Justus et Castor at the start of the school year and Joannes Callybita for the end of the first year of study. ${ }^{35}$

After Karl Habsburg's death the Breslau bishopric was taken over by Karl Ferdinand

${ }^{28}$ Cifra, Motecta [...] liber primus; Cifra, Motecta [...] liber secundus, and Cifra, Motecta [...] liber tertius. All three prints are today preserved at the Biblioteka Uniwersytecka in Warsaw (PL-Wu). Cf. Bohn, Bibliographie der Musik-Druckwerke, 101.

${ }^{29}$ Schmidl, Historiae Societatis Jesu, 2:718.

${ }^{30}$ Ibid., 2:408.

${ }^{31}$ Federhofer, Musikpflege, 51.

${ }^{32}$ Archivum Romanum Societatis Iesu (hereafter, ARSI), Austr. 133, 168.

${ }^{33}$ Prague, Národní Knihovna, Oddělení rukopisů a starých tisků (hereafter, CZ-Pn, ORST) XXIII C $105 / 1,114$.

${ }^{34}$ Hoffmann, "Zur Vorgeschichte der Breslauer Jesuiten-Universität", 109-110.

${ }^{35}$ Kroess, Geschichte, 2:1:303. 
Vasa (1613-1655), who resided mainly in Warsaw, Wyszków and Brok. When he came to Neisse, however, Vasa was honoured with theatrical spectacles staged by the students of the local gymnasium. ${ }^{36}$ The Jesuits of Neisse canvassed the support of the new diocesan bishop, since the further development of their teaching centre depended on his donations. They were also directly involved in the promotion of the new musical repertoire. One instance of their involvement is the first Catholic songbook printed in Silesia since the Reformation, which was published by Johann Schubart in $1625 .{ }^{37}$ Thanks to a foundation established by Anna Gebauer, the Jesuits also opened a boarding school in Neisse (1630), ${ }^{38}$ and the musicians educated there took active part in the city's musical life. The level of their performances must have been high, to judge from the fact that Karl Ferdinand eagerly listened to them on his visits to Neisse and even preferred them to his own private, professional ensemble. ${ }^{39}$

The musicians from the Jesuit boarding school in Neisse took part in catechetic street spectacles with a didactic purpose, such as some tableaux vivants staged in 1630, which represented the teachings of the Creed, the Ten Commandments and the Lord's Prayer. ${ }^{40}$ Such spectacles were presented during processions which passed under triumphal arches specially erected for the occasion. These spectacles were accompanied by gratissima phonascorum vocibus, instrumentis, canentium harmonia..$^{41}$ The student-musicians from Neisse additionally performed during school spectacles organised by the college, frequently ones on hagiographical subjects. At a spectacle dedicated to St Vitus, for instance, they sang a song in honour of that saint, and the text of the song was also distributed among the audience as an occasional publication. ${ }^{42}$ Two similar spectacles likewise honoured Karl Ferdinand during his visits to Neisse. On these occasions the plays were dedicated to the bishop's patron saints, St Carlo Borromeo (1650) ${ }^{43}$ and St Ferdinand (1652). ${ }^{44}$ Chroniclers noted that both spectacles were accompanied by music. The prelate beheld these spectacles magna voluptate, ${ }^{45}$ which may explain why he bequeathed his wealth to the Jesuits of Neisse for the purpose of building a new church, college and boarding school. ${ }^{46}$

This plan was carried out later, under the following Bishops of the Breslau diocese, which returned to Habsburg rule for another decade. Leopold Wilhelm, who was elected Bishop of Breslau in 1656, had already maintained a private musical ensemble, to which he recruited musicians from Saint Mark's in Venice, employing the mediation of the

${ }^{36}$ Already before Vasa's installation as bishop two dramas had been staged there on the subjects of St Gregory the Martyr and St Ignatius of Loyola. Schmidl, Historiae Societatis Jesu, 3:594-595.

${ }^{37}$ Catholische Kirchengesänge.

${ }^{38}$ Schmidl, Historiae Societatis Jesu, 3:1069-1070.

${ }^{39}$ Ibid., 4:2:622.

${ }^{40}$ Ibid., 3:1039-1040.

${ }^{41}$ CZ-Pn, ORST XXIII D 147, 177r.

${ }^{42}$ Schmidl, Historiae Societatis Jesu, 3:1058.

${ }^{43}$ ARSI Boh. 96, 578r.

${ }^{44}$ Schmidl, Historiae Societatis Jesu, 4:2:853.

45 Ibid., 622-623.

${ }^{46}$ ARSI Boh. 196, 248r-v. 
Jesuit Giacinto Cornacchioli. ${ }^{47}$ We have no information about his ensemble dating from the years of his residence in Neisse, but we know that he acted as the patron of several spectacles staged by students from the local gymnasium. ${ }^{48}$ Eulogistic licenze at the close of the final act were an indispensable element of such spectacles; in these the dramatis personae paid their homage to the bishop. ${ }^{49}$ From the musical point of view, such scenes were usually through-composed, a fact confirmed by chronicles from the time of the next Bishop of Breslau, Karl Joseph Habsburg (1649-1664). The teenage son of Ferdinand III, Holy Roman Emperor, was entertained by the Breslau boarding school musicians with musical-theatrical spectacles enriched ad choros musicos harmonia et concinuus ad eosdem numeros saltus. ${ }^{50}$

Jesuit authors from Schweidnitz, too, declared their political loyalty to the Habsburgs. This is evident from their mythological-historical dramas staged in that city, which pragmatically emphasise the links between the Duchy and the Emperor's rule. ${ }^{51}$ Even hagiographical plays celebrating the canonisation of Stanislaus Kostka and Aloysius Gonzaga $^{52}$ were not free from this obsequious quality. The panegyrical elements were especially prominent in spectacles presented by Jesuit colleges on the occasion of visits from members of the ruling dynasty. For Eleanor of Austria, Queen of Poland (1653-1697), the college in Neisse staged, in July 1675, a specially dedicated play in which the queen is likened to the moon, and her brother, Emperor Leopold I (1640-1705), to the sun. ${ }^{53}$

The list of participants attached to the perioche (summary) of this play names more than a hundred actors and 24 musicians, who - like the actors playing the main roles - were most likely pupils from the boarding school of St Anna in Neisse. Although the music for this spectacle does not survive, it evidently had a musical setting, as is also confirmed by the chronicler. ${ }^{54}$ The presence of a musical setting also finds corroboration in Johann Bernhardt Staudt's play Ferdinandus quintus rex Hispaniae, comparable in form and content but with an extant musical score in addition to the perioche and libretto. ${ }^{55}$ The last-named spectacle was revived several years later by students at the Jesuit college in Vienna. A contemporary source of that Viennese spectacle establishes that several parts were through-composed, including an epilogue taking the form of a eulogistic licenza. ${ }^{56}$

The Jesuit music played for Habsburg dynasts was also cultivated in the borderlands between Silesia and the Polish-Lithuanian Commonwealth. The Jesuits of Tarnowskie Góry, a town in the Cracow diocese, were financially supported by a foundation established by

${ }^{47}$ Saunders, Cross, Sword, and Lyre, 7.

${ }^{48}$ These were, for instance, spectacles on the subject of Solomon (CZ-Pn, ORST XXIII C 105/2, 213v), the Japanese Martyrs (ARSI Boh. 97 I, 348), St John the Baptist (ARSI Boh. 97 II, 463r), St Sebastian, St Ignatius of Loyola and David and Goliath (ARSI Boh. 98, 304).

${ }^{49}$ Christianus agon.

${ }^{50}$ ARSI Boh. 98, 629.

${ }^{51}$ Aquila Principaliorum Duorum Sanctorum; Bolcopolis seu nobile Schwidnicium.

${ }^{52}$ Cultus Angelicus. Hoffmann, Die Jesuiten in Schweidnitz, 125-126.

${ }^{53}$ Luna Austriaca.

${ }^{54}$ ARSI Boh. 102, 557-558.

${ }^{55}$ Vienna, Österreichiche Nationalbibliothek, Cod. 18875.

${ }^{56}$ Staudt, Ferdinandus Quintus. 
Eleanor of Austria but belonged to the Czech-speaking regions of the same province of the Society, thus being more likely to represent the interests of the Viennese Habsburgs rather than those of Andrzej IV Trzebicki, Bishop of Cracow. ${ }^{57}$ Their mission was of strategic importance not only from a political, but also from a religious, standpoint, since it was placed in charge of the church in Piekary, where the recently recovered image of Mater Admirabilis became the subject of a growing cult that was not, however, approved of by Bishop Trzebicki within his diocese. ${ }^{58}$ For the Jesuits, the image of Our Lady of Piekary afforded an ideal pretext for the cultivation of the vernacular repertoire, including Polish-language songs performed during the liturgy. ${ }^{59}$ Marian songs, too, were sung in front of a copy of Cranach's Maria Hilf, which in 1698 was moved to the Jesuit church in Breslau from the collection of Bishop Leopold Wilhelm. Originally, this votive painting attracted secular worshippers, who sang a German version of the Ave Maria $;{ }^{60}$ later, the Jesuits established a regular foundation for the singing of the antiphon Salve Regina on Saturday afternoons and Marian feast-days, and on the vigil of major feasts in the liturgical year. The antiphon was performed by an eight-strong mixed vocal-instrumental ensemble made up of boarders from the Jesuit school and funded by the interest on the capital invested in the foundation. ${ }^{61}$

Habsburg patronage also provided support for the sodalities founded by the Jesuits, whose honorary members - frequently from the ruling dynasty - contributed higherthan-normal donations to their budget. This was true not only of Karl Habsburg, listed among the members of the Congregation of the Annunciation of the Holy Virgin Mary in Neisse, ${ }^{62}$ but also of Emperor Ferdinand II, Archduke Leopold Wilhelm and Cecilia Renata of Austria, who left entries in the album of that sodality. ${ }^{63}$ The importance of imperial patronage for the Jesuit sodalities distinctly emerges from the album of the Corpus Christi Confraternity of Schweidnitz, which opens with a card dedicated to the cult of the Eucharist, whose dominant graphic elements are the eagle and the coats of arms of the Domus Austriacae (figure 2) ${ }^{64}$ Habsburg patronage also allowed the art created in Jesuit circles to be disseminated on a geographically very extensive scale, making that art universal while at the same time spreading the political propaganda prescribed by the court in Vienna.

The participation of members of the Emperor's family and its supporters in public Corpus Christi processions endowed the proud countenance of Ecclesia triumphans with definitive personal features. It was simultaneously a manifestation of their secular power and a celebration of their political triumphs. Victorious generals returning from the battlefield rode under triumphal arches constructed by Jesuit architects, while Jesuit

${ }^{57}$ Kroess, Geschichte, 3:901.

${ }^{58}$ Hoffmann, Die Jesuiten in Oppeln, 215.

${ }^{59}$ Hoffmann, Die Jesuiten in Oppeln, 262.

${ }^{60}$ Kuźmak, Bractwa Matki Boskiej, 65-68.

${ }^{61}$ ARSI Boh. 152, 277.

${ }^{62}$ Schmidl, Historiae Societatis Jesu, 3:563.

${ }^{63}$ Album Almae Congregationis Annunciatae (1739). Hoffmann, Die Jesuiten in Glogau, 62-63.

${ }^{64}$ Album of the Corpus Christi Confraternity in Schweidnitz, Świdnica, Library of St Wenceslas and St Stanislas Cathedral (no shelfmark). 


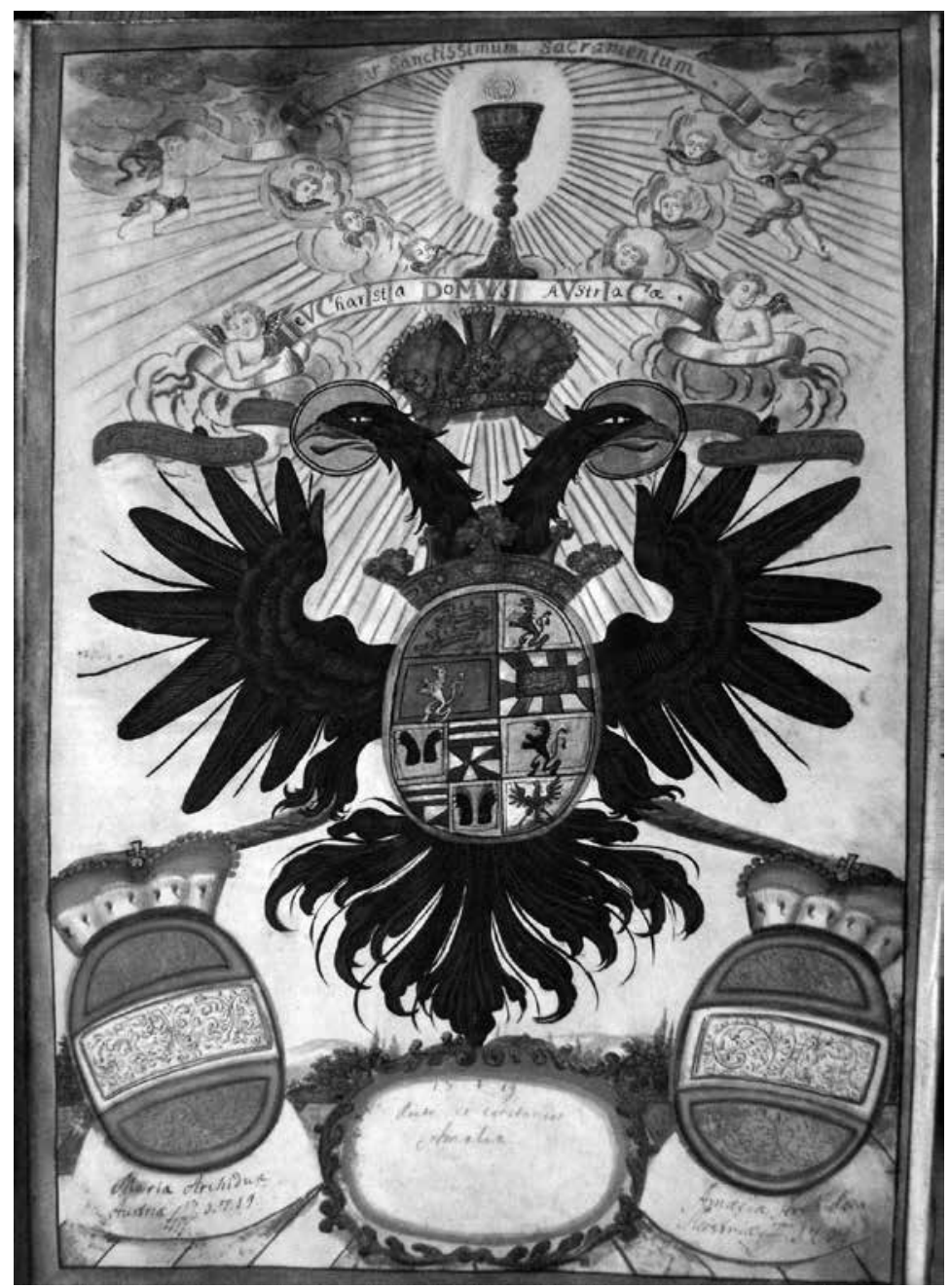

Figure 2

Album of the Corpus Christi Confraternity in Świdnica (Ger. Schweidnitz), Library of St

Wenceslas and St Stanislas Cathedral (reproduced with kind permission)

school students placed upon these arches played music for the victors. College principals made propagandistic statements evaluating the victories and interpreting them to the public. ${ }^{65}$ The military successes of the imperial armies during the anti-Turkish campaign in Hungary ${ }^{66}$ and the War of the Spanish Succession ${ }^{67}$ were celebrated with a solemn Te Deum. In Silesian Jesuit churches special celebrations were held to mark imperial elections, enthronements and coronations, and to pay homage to the rulers. On his tour of the Silesian cities the newly elected Czech king Ferdinand IV was greeted and honoured as overlord in Breslau, Neisse, Glatz and Schweidnitz, which had only recently become

\footnotetext{
${ }^{65}$ ARSI Boh. 96, 417.

${ }^{66}$ ARSI Boh. 104 II, 722.

${ }^{67}$ ARSI Boh. 122, 107.
} 
absorbed into the imperial territories. The pompa festiva held in the last city had a special propagandistic significance: it included a votive Mass to the Holy Ghost and a Te Deum inter tympanorum et tubarum applausus. ${ }^{68}$

Most spectacular, however, were the celebrations held for the birth of heirs to the imperial throne, such as that of Ferdinand Wenceslaus, the first-born son of Leopold I, and later that of Leopold Joseph. ${ }^{69}$ On the first occasion, a solemn votive Mass de S. Trinitate and a Te Deum was sung in Glatz..$^{70}$ The name-days and birthdays of Emperor Leopold I, benefactor of the Jesuit order ${ }^{71}$ and founder of Breslau Academy (named the Leopoldina after his name ${ }^{72}$ ), were even celebrated with a special liturgy. The pompae funebres organised in Jesuit churches after the deaths of the Habsburg bishops Karl ${ }^{73}$ and Leopold Wilhelm, ${ }^{74}$ as well as those of the successive emperors, can similarly be regarded as a vehicle for political propaganda. These liturgies were accompanied by several-day-long exequies and by exquisitus musicorum concentus,${ }^{75}$ which aimed to convince the audience that the relationship between the Jesuits (representing the Church) and the secular power extended beyond the time and space of the visible world.

The political function of such musical performances derived mostly from their persuasivepropagandistic and representative qualities, of which practical advantage was taken on a large scale. ${ }^{76}$ Through the ceremonials of authority music came to constitute a kind of "mediastrategic system for the creation and maintenance of power". ${ }^{77}$ This idea was not only the actual practice of the elites ruling over the major part of our continent: it was even advocated as a doctrine by Athanasius Kircher, who in one of the last chapters of his Musurgia universalis (Symphonismus mundi politici sive de musica politica) ${ }^{78}$ formulated the theory of musica politica..$^{79}$ In addition to describing political reality, Kircher's conception sought and found arguments to justify this partisan role in a well-governed monarchy, which he regarded as the best of all political systems on the basis of its similarity to the harmonic order of both the physical and metaphysical constituents of Nature.

Translated by Tomasz Zymer

${ }^{68}$ Wrocław, Archive of the Wrocław Archdiocese (further referred to as WAAW), V 46, 33.

${ }^{69}$ WAAW V 45, 104r.

${ }^{70}$ CZ-Pn, ORST XXIII D 168, 216.

${ }^{71}$ ARSI Boh. 102, 682.

${ }^{72}$ ARSI Boh. 114, 347.

${ }^{73}$ ARSI Boh. 93, 253.

${ }^{74}$ ARSI Boh. 98, 628.

${ }^{75}$ CZ-Pn, ORST XXIII C 105/2, 198r.

${ }^{76}$ Spohr, "Concealed Music in Early Modern Diplomatic Ceremonial", 19-20 and 35-36.

${ }^{77}$ Berns, "Instrumental Sound and Ruling Spaces", 479.

${ }^{78}$ Kircher, Musurgia universalis, 432-440.

${ }^{79}$ Scherliess, "Musica politica", 270-283. 


\section{Sources and Bibliography}

\section{ArChival SOURCES}

Archivum Romanum Societatis Iesu

ARSI Austr. 133 - Litterae Annuae Provinciae Austriae (1600-1617)

ARSI Boh. 93 - Litterae Annuae Provinciae Bohemiae (1593-1626)

ARSI Boh. 96 - Litterae Annuae Provinciae Bohemiae (1641-1644, 1646-1650)

ARSI Boh. 97 I-II - Litterae Annuae Provinciae Bohemiae (1651, 1658-1660)

ARSI Boh. 98 - Litterae Annuae Provinciae Bohemiae (1661-1664)

ARSI Boh. 102 - Litterae Annuae Provinciae Bohemiae (1674, 1675, 1679)

ARSI Boh. 104 II - Litterae Annuae Provinciae Bohemiae (1682, 1683, 1685)

ARSI Boh. 114 - Litterae Annuae Provinciae Bohemiae (1702)

ARSI Boh. 122 - Litterae Annuae Provinciae Bohemiae (1710)

ARSI Boh. 152 - Litterae Annuae Provinciae Bohemiae (1734)

ARSI Boh. 196 - Fundationes Provinciae Bohemiae

Praha, Národní Knihovna, Oddělení rukopisů a starých tisků

CZ-Pn, ORST XXIII C 105/1 - Litterae Annuae provinciae Bohemiae (1608-1616)

CZ-Pn, ORST XXIII C 105/2 - Litterae Annuae provinciae Bohemiae (1654-1659)

CZ-Pn, ORST XXIII D 147 - Historiae collegiorum S. J. provinciae Bohemiae

CZ-Pn, ORST XXIII D 168 - Excerpta ex Historia Collegij Glacensis Societatis Jesu

Wrocław, Archive of the Wrocław Archdiocese

WAAW V 45 - Historia Svidnicensis Domicilii Societatis Iesu

WAAW V 46 - Collecta quaedam pro historia Collegij Svidnicensis Societatis Iesu

\section{EARLY PRINTS}

Aquila Principaliorum Duorum Sanctorum Stanislai Episcopi, \& Wenceslai Bohemiae

Regis, Martyrum. Schweidnitz: Johann E. Okel, [1703].

Catholische Kirchengesänge und geistlich Lieder. Neisse: Johann Schubart, 1625.

Christianus agon nobilis in Japonia neophyti decertatus. Neisse: Ignaz K. Schubart, 1658.

Bolcopolis seu nobile Schwidnicium adversus minus propitiorum Deorum fata aeterna-

turo Jovis praesidio gratiosae munitum. Schweidnitz: Johann Ch. Müller, [1736].

Bonometti, Giovanni Battista, ed. Parnassus musicus Ferdinandaeus. Venice: Giacomo Vincenti, 1615. RISM 1615

Cifra, Antonio. Motecta quae binis ternis quaternis vocibus concinuntur [...] liber primus.

Venice: Giacomo Vincenti, 1610. RISM C 2163.

___ Motecta quae binis ternis quaternis vocibus concinuntur [...] liber secundus.

Venice: Giacomo Vincenti, 1610. RISM C 2169.

__- Motecta quae binis ternis quaternis vocibus concinuntur [...] liber tertius. Venice:

Giacomo Vincenti, 1610. RISM C 2175.

Cultus Angelicus ad perpetuam memoriam Sanctorum Aloysii et Stanislai velut Recentium

Caelestis Paradisi Florum Romae primum. N. p., n. d.

Kircher, Athanasius. Musurgia universalis sive ars magna consoni et dissoni. Rome:

Francesco Corbeletti, 1650.

Luna Austriaca, Serenissima Regina Eleonora. Neisse: Ignaz K. Schubart, 1675. 
Poss, Georg. Liber primus missarum octonis et senis vocibus. Graz: Georg Widmanstetter, 1607. RISM P 5245.

Orpheus mixtus vel, si mavis concentus musici, tam sacris, quam profanis usibus elaborati, tam simulatis instrumentorum [...] quibus vox octava initium sextadecima finem scribit. Graz: Georg Widmanstetter, 1607. RISM P 5246.

Valentini, Giovanni. Salmi, hinni, Magnificat, antifone, falsi bordoni et motetti concertati a una, due, tre e quattro voci, con il basso per l'organo. Venice: Giacomo Vincenti, 1618. RISM V 90.

- Sacri Concerti a due, tre, quattro et cinque voci. Con il Basso Continuo. Venice: Giacomo Vincenti, 1625.

\section{LITERATURE}

Berns, Jörg Jochen. "Instrumental Sound and Ruling Spaces of Resonance in the Early Modern Period: On the Acoustic Setting of the Princely potestas Claims within a Ceremonial Frame". In Instruments in Art and Science: On the Architectonics of Cultural Boundaries in the 17th Century, edited by Helmar Schramm, Ludger Schwarte and Jan Ladzardzig, 479-506. Berlin: De Gruyter, 2008. https://dx.doi. org/10.1515/9783110971910.479.

Bohn, Emil. Bibliographie der Musik-Druckwerke bis 1700 welche in der Stadtbibliothek, der Bibliothek des Akademischen Instituts für Kirchenmusik und der Königlichen- und Universitäts-Bibliothek zu Breslau aufbewahrt werden. Ein Beitrag zur Geschichte der Musik im XV, XVI, und XVII Jahrhundert. Berlin: Commissions-Verlag von A. Cohn, 1883.

___ Die musikalischen Handschriften des XVI und XVII Jahrhunderts in der Stadtbibliothek zu Breslau. Breslau: Commissions-Verlag von Julius Hainauer, 1890. Bireley, Robert. Religion and Politics in the Age of the Counterreformation: Emperor Ferdinand II, William Lamormaini, S. J., and the Formation of Imperial Policy. Chapel Hill: University of North Carolina Press, 1981.

Federhoffer, Helmuth. "Graz Court Musicians and their Contributions to the Parnassus Musicus Ferdinandeus (1615)”. Musica Disciplina 9 (1955), 167-244.

___ Musikpflege und Musiker am Grazer Habsburgerhof der Erzherzöge Karl und Ferdinand von Innerösterreich (1564-1619), Mainz: B. Schott's Söhne, 1967.

Hoffmann, Hermann. Die Jesuiten in Glogau. Breslau: Kommissionsverlag der Schlesischen Volkszeitung 1926.

—__ Die Jesuiten in Oppeln: Die Tätigkeit der Jesuiten in d. Fürstentümern Oppeln u. Ratibor, den Standesherrschaften Beuthen und Pleß, in Oberglogau und Ziemientzitz, in Oppeln Tarnowitz und Piekar, in den Volksmissionen und den neuen Niederlassungen. Breslau: Frankes Verlag, Otto Borgemeyer, 1934.

____ "Zur Vorgeschichte der Breslauer Jesuiten-Universität". Zeitschrift des Vereins für Geschichte (und Altertum) Schlesiens 68 (1934), 107-117.

Jeż, Tomasz. Kultura muzyczna jezuitów na Śląsku i ziemi kłodzkiej 1581-1776 [Musical Culture of the Jesuits in Silesia and Glatz County, 1581-1776]. Warsaw: Wydawnictwo Naukowe Sub Lupa, 2013. 
Kastner, August. Archiv für die Geschichte des Bisthums Breslau. Neisse: Im Selbstverlage des Herausgebers, 1858.

Kroess, Alois. Geschichte der böhmischen Provinz der Gesellschaft Jesu: Nach den Quellen bearbeitet. Vol. 1, Geschichte der ersten Kollegien in Böhmen, Mähren und Glatz von ihrer Gründung bis zu ihrer Auflösung durch die böhmischem Stände 1556-1619. Quellen und Forschungen zur Geschichte, Literatur und Sprache Österreichs und seiner Kronländer, 11. Vienna: Mayer, 1910.

Geschichte der böhmischen Provinz der Gesellschaft Jesu: Nach den Quellen bearbeitet. Vol. 2, bk. 1, Beginn der Provinz, des Universitäts-Streites und der Katholischen General-Reformation. Bis zum Frieden von Prag 1635. Quellen und Forschungen zur Geschichte Österreichs und der angrenzenden Gebiete, 13. Vienna: Mayer, 1927

___ Geschichte der böhmischen Provinz der Gesellschaft Jesu: Nach den Quellen bearbeitet. Vol. 2, bk. 2, Vom Prager Frieden 1635 bis zum Tode Ferdinands III. im Jahre 1657. Quellen und Forschungen zur Geschichte Österreichs und der angrenzenden Gebiete, 14. Vienna: Mayer, 1938.

- Geschichte der böhmischen Provinz der Gesellschaft Jesu: Nach den Quellen bearbeitet. Vol. 3, Die Zeit von 1665 bis zur Aufhebung der Gesellschaft Jesu im Jahre 1773: Neu bearbeitet und ergänzt von P. Karl Forster SJ. Prague: Česka provincie Tovaryšstva Ježišova; Olomouc: Refugium Velehrad-Roma, 2012.

Kuźmak, Krystyna. Bractwa Matki Boskiej Wspomożycielki Chrześcijan na ziemiach polskich w XVIII stuleciu: Studia z dziejów kultu maryjnego i wspólnot chrześcijańskich w dawnej Polsce [Confraternities of Mary Help of Christians in the Polish Territories in the 18th-Century: Studies in the History of Marian Cult and Christian Communities in Poland]. Rome: Pontificio Istituto di Studi Ecclesiastici, 1973.

Przybyszewska-Jarmińska, Barbara. "Starania biskupa wrocławskiego Karola Habsburga o pozyskanie włoskich śpiewaków (1621-1622)" [Karl Habsburg, the Bishop of Wrocław's Efforts to Employ Italian Musicians (1621-1622)]. Res Facta Nova 6, no. 15 (2003): 127-134.

Saunders, Steven. Cross, Sword, and Lyre: Sacred Music at the Imperial Court of Ferdinand II of Habsburg (1619-1637). Oxford: Clarendon Press, 1995.

"Der Kaiser als Künstler. Ferdinand III and the Politicization of Sacred Music et the Hapsburg Court”. In Infinite Boundaries: Order, Disorder, and Reorder in Early Modern German Culture, edited by Max Reinhart, 187-207. Sixteenth-Centuries Essays and Studies, 40. Kirksville, MO: Truman State University Press, 1998.

- "The Hapsburg Court of Ferdinand II and the Messa, Magnificat et Iubilate Deo a sette chori concertati con le trombe (1621) of Giovanni Valentini”. Journal of the American Musicological Society 44, no. 3 (1991): 359-403. https://doi. org/10.2307/831644.

Scherliess, Volker. "Musica politica". In Festschrift Georg von Dadelsen zum 60. Geburtstag, edited by Thomas Kohlhase and Volker Scherliess, 270-283. Neuhausen-Stuttgart: Hanssler-Verlag, 1978.

Schmidl, Johann. Historiae Societatis Jesu provinciae Bohemiae. Vols. 1-4. Prague: Academic Printing House, 1747-[1759]. 
Seifert, Herbert. Die Oper am Wiener Kaiserhof im 17. Jahrhundert. Tutzing: Hans Schneider, 1985.

Spohr, Arne. "Concealed Music in Early Modern Diplomatic Ceremonial". In Music and Diplomacy from the Early Modern Era to the Present, edited by Rebekah Ahrendt, Mark Ferraguto and Damien Mahiet, 19-44. New York: Palgrave Macmillan, 2014. https://dx.doi.org/10.1057/9781137463272_2.

Staudt, Johann Bernhard. Ferdinandus Quintus Rex Hispaniae Maurorum Domitor: Drama des Wiener Jesuitenkollegs anläßlich der Befreiung von der Türken 1683, edited by Walter Pass. Denkmäler der Tonkunst in Österreich, 132. Graz: Akademische Druck- u. Verlagsanstalt, 1981.

Wiermann, Barbara. Die Entwicklung vokal-instrumentalen Komponierens im protestantischen Deutschland bis zur Mitte des 17 Jahrhunderts. Göttingen: Vandenhoeck \& Ruprecht, 2005. 
GLASBENO MECENSTVO HABSBURŠKE DINASTIJE V JEZUITSKI ŠLEZIJI

\section{Povzetek}

V procesu širjenja novega italijanskega sloga duhovne monodije po Evropi zgodnjega 17. stoletja so pomembno vlogo odigrali Habsburžani. Njihovemu siceršnjemu pomenu za zgodovino in kulturo svojega časa je treba dodati še tesne stike nekaterih družinskih članov, ki so vladali v številnih predelih tedanje Evrope, z jezuiti, ki so tedaj sodili med najpomembnejše cerkvene redove. Dolgoročne zveze med posvetnimi oblastmi in duhovno elito so v potridentinskem času ustvarile posebno družbeno simbiozo, katere poznavanje je za razumevanje zgodnje novoveške kulture prvorazrednega pomena.

Ta fenomen zlahka opazimo predvsem na področjih velikih verskih konfrontacij, kot je bila na primer tudi Šlezija, ki jo je tedaj doletela tako posvetna kot tudi verska preobrazba. Eno od učinkovitih orožij v tej kulturni preobrazbeni vojni je bila glasba, ki so jo v teh krajih izvajali učenci v jezuitskih internatskih šolah in ki so jih financirali Habsburžani: tako več zaporednih cesarjev kot tudi nekateri njihovi otroci, ki so imeli v Šleziji pomembne politične položaje. Obe strani sta glasbo pojmovali kot svoj družbeno prepoznavni jezik in orodje prenove identitete lokalne družbe na najrazličnejših ravneh: od župnij, mest, vojvodin in dežel do cesarstva in stvarstva.

Stalna prizadevanja za podporo glasbi, ki so jo stimulirali Habsburžani in jo izvajali jezuitski krogi, se niso omejevala na rezidence in domače cerkve podpornikov. Nova zvočnost te kulture se je hitro udomačila v mestni svetih, šolah ter mestnih ulicah in trgih. Glasba, ki se je izvajala v teh okoljih, je v prvi vrsti pragmatično sledila trenutnim praktičnim potrebam. Te žal niso bile v prid njenemu ohranjanju za prihodnost. Zavedajoč se glasbenega okusa članov habsburške dinastije ne gre podcenjevati tudi njene same umetniške vrednosti. Arhivski viri, ki sovpadajo z ohranjenimi muzikalijami iz omenjenih okolij, to tudi potrjujejo. 